FACTA UNIVERSITATIS

Series: Physical Education and Sport, Vol. 18, No 1, 2020, pp. 169 - 178

https://doi.org/10.22190/FUPES200226014M

Professional article

\title{
THE ROLE OF THE TEACHER IN THE APPLICATION OF INCLUSIVE TEACHING OF THE SUBJECT NATURE AND SOCIETY IN REGULAR CLASSES

\author{
UDC 615.001
}

\author{
Ljiljana Mitić ${ }^{1}$, Ana Drobac ${ }^{2}$ \\ ${ }^{1}$ Pedagogical Faculty, University of Niš, Vranje, Serbia \\ ${ }^{2}$ Faculty of Special Education and Rehabilitation, University of Belgrade, Belgrade, \\ Serbia
}

\begin{abstract}
The main aim of this paper is to point out the specifics of teachers' work in teaching the subject Nature and Society, using different forms of teaching, learning and assessment, which ensure equal access to education for all children in accordance with developmental and personal educational affinities, and age. The paper focuses on a teachers' need for education, expertise, knowledge and the skills necessary for inclusive teaching of the subject Nature and Society in regular classes with students with disabilities. The importance of the teachers' role in the teaching process with students with disabilities has been emphasized, in relation to their integration and inclusion into normal life. The success of an education system is reflected in attracting, and choosing the right candidates, capable people for work in the classroom, which contributes to greater and better student achievement.
\end{abstract}

Key words: Inclusion, Integration, Teacher, Student.

\section{INTRODUCTION}

Inclusion in the education of students in the elementary grades and their integration into regular classes is an indispensable issue of the modern educational system, understood as a process which would ensure quality education for all students, respecting their various needs, abilities and expectations. It also carries with it certain challenges for society, schools and social participation.

The most important assumption in the education of students with disabilities is that teachers are trained to work in regular schools, under inclusive conditions. Initial education

Received February 26, 2020/ Accepted April 07, 2020

Corresponding author: Ljiljana Mitić

Pedagogical Faculty, University of Niš, Partizanska 14, 17500 Vranje, Serbia

Phone: + 17 421633• E-mail: ljiljanamitic017@gmail.com 
and continuous professional development of teachers play a key role in developing positive attitudes towards inclusion, as well as developing knowledge and skills that are necessary for the work in an inclusive environment (Forlin, 2013).

In educational work, the people who make the changes most often are teachers, because they are a key factor in the successful implementation of inclusive education in the school as a basic factor of educational work. Teachers are expected to be experts both in the subject they teach and in the field of teaching in general. In order to accomplish this, they have to continually improve their own knowledge and reflect on their own practice (Momčilović \& Momčilović, 2016). Their acceptance of inclusion in the field of education is the promotion of inclusive values and is focused on the creation and implementation of teaching units in the curriculum.

The term inclusion implies the process of involving students with disabilities into regular work programs, with an emphasis on the individualization of students with disabilities and their mutual integration. All students have equal development opportunities and chances of success, and they participate actively in teaching activities, creating a positive environment based on tolerance and respect.

The term integration is associated with a number of unresolved problems, of which the most significant is the lack of support for the full integration of students with disabilities in regular classes. The difference between these two concepts refers to the difference between belonging to the inclusive and fitting in the integrated process. Inclusion implies a change in circumstances in regular schools for the purpose of customization of students with disabilities, or to create such an atmosphere in which every student, regardless of the type of interference, would feel comfortable and able to develop in every way.

Bearing in mind that inclusive education has only recently become a topic in our country, the question arises: How do teachers fulfill their professional obligations?

It is crucial that the teacher is capable of quality implementation of educational practice. Ilić (2009) gives great attention to the dimension of inclusive education, and speaks about the inevitability of the professional competence of educational workers - teachers, as well as their methods and methodological skills. Methodological skills are linked to identifying the individual's differential learning disparity, while the methods are linked to developing and implementing programs and models of individual interactive and joint learning in inclusive teaching.

The main aim of this paper is to point out the specifics of teachers' work in the teaching of the subject Nature and Society, using different forms of teaching, learning and assessment, which ensure equal access to education for all children in accordance with developmental and personal educational affinities and age.

\section{The role of teachers in integrating students with disabilities into regular classes}

The success of the education system is reflected in attracting, and choosing the right candidates, people capable of teaching, which contributes to the higher and better achievements of students. This is achieved by selecting people with a high level of linguistic, mathematical and general educational literacy, possessing strong interpersonal and communication skills, a great will for learning and motivation for teaching. Increasing teacher knowledge in strategies and knowledge of both inclusion and mainstreaming can assist teachers in feeling better prepared to work with students with disabilities (Alfaro, Kupczynski \& Mundy, 2015). 
Teachers are the main factor in educational work, and represent a key factor for the successful implementation of inclusive education in school. Their professional development is a necessary driver for schools, and their acquisition of knowledge and skills enables them to be good teachers and educators. Teachers have the power to improve, develop, and make the difficulties acceptable, using didactic-methodical procedures. Together with their abilities and possibilities, they can create a positive atmosphere, which ultimately aims to socialize students. Effective teachers display a wide range of skills and abilities that lead to creating a good learning environment. Knowledge of content must be balanced with a solid grounding in effective teaching strategies (Amusan, 2016).

The role of teachers, which refers to the integration of students with disabilities in regular classes, is extensive and recognized in theory. The concepts of integration and inclusion differ: integration implies simply transferring children with developmental disabilities from special schools to regular schools, while inclusion, as a concept that is put before schools and society, demands certain changes be made in order to adjust the school environment to students with disabilities. It is where the importance of the teachers' role emerges.

As seen in the literature, the role of teachers is one of the most important factors for the functional implementation of social inclusion. The professional standard for teachers, which makes demands on the personal qualities of a teacher is developed: the readiness to teach all children regardless of their inclinations, abilities, disabilities, limited opportunities (Fahrutdinova, Yarmakeev, \& Fahrutdinov, 2016). Cox (1993, according to Gilligan, 1998, p. 572) states that school factors that promote positive behavior and good adaptation of children with disabilities include "high expectations for work and behavior, teachers as good models of behavior, respect for children and their ability to achieve, so that children could be included in school, clear disciplinary rules, encouraging good behavior and careful use of punishment, pleasant working conditions, a good teacher-student relationship, and a coherent support structure for teachers". The relationship with the teacher in many ways affects the child's academic, cognitive and social development and adaptation. The teacher is a motivator and the creator of future relationships of joint activities, which would facilitate understanding between them, and thus contribute to the development of students. Good relationships between teachers and students are characterized by a high level of closeness and low level of conflict, which contributes to a positive affect and open communication, lack of difficulty in managing the behavior of the child. Their good relations create an atmosphere of support and emotional security in which students feel confident and supported. According to Pianta (1999) "in these conditions, children are better able to organize and manage their emotions, engage in effective interactions with others, confidently explore resources of classrooms and departments, involve in class activities and focus on learning".

Teachers are expected to adjust their work to students with disabilities and the dynamics of the group that is changed significantly when classes are attended by students with disabilities, depending on the type of disability. A teacher's competencies are very important for the implementation of inclusive education and are embedded in the competencies related to the professional abilities of teacher, where they are most prominent: the teacher's belief that all students can learn; respecting students as individuals; respecting the dignity of students; perseverance in helping all students achieve success; as well as respect for diversity.

A teacher's pedagogical skills are characterized by the management of the classroom, personal responsibility for the progress of each student, the motivation of students to act 
in a way that meets their personal needs and the needs of the classroom. The teacher works to reduce obstacles in working with students, possesses mediation skills for solving problems, promotes a positive relationship between students, engages students for individual and competent teaching activities, and supports the development of common values, interaction, academic discussion, individual and group responsibility in order to create a positive climate and respect in the department. A teacher possesses pedagogical knowledge for inclusive education. It is necessary to include knowledge, abilities and skills, in order to review and understand the educational process, which should be adapted to inclusive conditions. Teachers possess psychological skills, which include the knowledge and ability of his adapting to students with disabilities, monitoring their progress and identifying the difficulties that students have in the learning process. Their methodical skills are reflected in the planning and preparation of the class and the use of all methods, learning techniques, the use of educational didactic means, a modern approach to teaching, skills of including students in the teaching process, and the development of critical thinking.

\section{Preparing teachers for inclusive teaching}

With a change in the role of teachers and students, newer and harder demands are placed before the teacher, where the teacher is assigned a central role in developing the idea of schools for all, the idea of guiding for individualization and inclusion in education. The development of inclusion gives the teacher a central role, and therefore the need for education in accordance with the requirements of inclusion, at the level of general and professional development. If a teacher wants to be successful, s/he needs to keep up with modern times, because as the students change, their needs change too, and so do the inevitable and professional changes of the teachers who are dealing with them. Teachers are forced to innovate their practice, and lifelong learning is a common denominator of various forms of learning in order to improve the teacher's competence. It is necessary that teachers, being informed about modern tendencies in education, acquire new knowledge, read professional literature, and attend seminars in accordance with their needs. Given the change in student population needs, the skills and competencies of general education teachers must be buttressed to meet the diverse needs of diverse students (Shaffer \& Thomas-Brown, 2015).

The educational system of future teachers must ensure the equal right and access to education and upbringing, and the acquisition of knowledge through various forms of teaching and learning. In addition to knowledge and skills, an integral part of teacher competencies are value attitudes that are not subject to assessment in higher education institutions that educate future pedagogical workers.

The Bologna way of studying and adapting higher education has led to the introduction of new subjects at the faculties of Teacher Training, Sport and Physical Education and pedagogical faculties, in order to acquire knowledge for working with students with disabilities, and to the possibility of specializing in elective subjects for work specialists. Colleges, including the Teacher Education Faculty in Belgrade, University of Belgrade and the Pedagogical Faculty in Vranje, University of Niš, introduced a mandatory course into their programs - Methods on Working with Children with Disabilities, while at the Faculty of Education in Jagodina, University of Kragujevac gaining knowledge in this field is represented in the subject Methods of Special Work with Mildly Disturbed Students. At the 
Faculty of Sport and Physical Education, University of Niš there are mandatory courses Adaptive Physical Exercise and Sports for Individuals with a Physical Disability (Jorgić et al., 2014), while the course - Sports for Individuals with a Physical Disability is an elective one at the Faculty of Sport and Physical Education, University of Belgrade.

It is well known that a school is worth as much as the sum value of the teachers who work in it. Although teachers have acquired the knowledge and skills necessary for the development of the average student during his studies, in order to perform the task and to participate in the education and upbringing of students with disabilities, they need to improve constantly. Teacher education requires links to all educational structures, and Darling and Hamond (2006) point out that the field of teacher training must inevitably continue to develop away from the academic environment towards a closer connection to schools on the ground and their common plan to change, with all the potential problems that can be encountered. Hoban and Hoban (2004) believe that such a plan must be based on four aspects: conceptual links between university curricula; the connection between theory and practice in the school and university environment; social and cultural links between participants in the program. They conclude that the social and cultural dimension is one that includes the other three, emphasizing that the social interaction between participants is the one that enables the program to be dynamic and modifiable according to the relevant cultural and political needs, whereby communication is at the heart of a coherent educational program for teachers. Inclusion is, among other things, life without prejudice.

The European Agency for Human Rights (2010) prepared a teacher profile that covers the following areas of knowledge, experience and skills: evaluating students' idiosyncrasies; support for all students; working with others, and personal professional development. Teachers are not just lecturers, but organizers who have to devise new ways of working with students and to have control in the classroom. An inclusive teacher uses the approach of learning, at center of which is the student. Such an approach is characterized by respect for each student, and working with him as a person. A teacher understands diversity among students and does not use students' characteristics to categorize and label them. In order for a teacher to become inclusive, s/he must go through the transformation of identities and basic theses that are managed in practical teaching.

Teacher education should include a comprehension of differences that may be related to culture, language, family, pre-education, differences in the developmental level of intelligence, a preferred learning style, or specific learning difficulties. Teachers need to recognize the importance of understanding motivation, possessing certain types of learning knowledge, and having the skills to use a wide range of techniques to evaluate / assess student knowledge. They need to gain knowledge on the management strategies of education, according to the different styles, they should know the resources of curriculum and technology, have knowledge of cooperation with students, parents and other educators, and to be qualified for analysis of their own work in order to evaluate the effects of their knowledge.

The professional development of future teachers, educators and professional associates, has the goal of acquiring knowledge and skills for working with students with disabilities. Although the Rulebook on Continuing Professional Development prescribes the necessity of attending the program in the form of a hundred hours of realization and professional development of teachers, educators and professional associates, the data indicates an insufficient number of professional development programs. 


\section{Basic characteristics of the inclusive teaching of the subject Nature and Society in regular classes}

The areas of inclusive education are being upgraded every day, taking their own place in the regular teaching process through all subjects of elementary school education. An elementary school teacher has to synthesize methodological knowledge of individual disciplines into a single unit. This provision serves as a prerequisite for the allocation of the methodological sphere of the professional activity of teachers working in elementary grades (Akhmedova, 2019). Physical activity (walking, discovering nature, etc.) are an integral part of the inclusive approach to teaching. Studies show that as many students with disabilities as possible should be included in regular classes. The possibilities of involving these students in the curriculum of the subject Nature and Society are big and they oblige teachers to improve and acquire knowledge and skills to work with these students.

There is a huge difference between the individual involvement of students with disabilities in regular classes and the inclusion of students in the education system with students with no developmental disabilities. It is therefore important that teachers of all subjects, including the subject Nature and Society, prepare to work with students with disabilities, especially when it comes to classes spent in nature.

In regular classes, to work with students with disabilities, teaching contents, methods of work and work programs for the classes of the subject Nature and Society, must be adapted to them, so that students with disabilities would not feel uncomfortable, and their (motor, psychic, emotional) characteristics would develop in the right way. The contents that teachers adapt to these students in the subject Nature and Society should enable students with disabilities to feel socially accepted, useful, satisfied, happy, and fulfilled. During these classes, students develop and improve motor skills, strengthen their body, gain experience, safety and self-confidence, a sense of acceptance from their peers, a sense of community and cooperation with other students. If the curriculum is not a tailor-made curriculum that suits them, students with disabilities can feel discriminated and discarded, and hence, because the activities are not in accordance with their abilities, they will not be able to participate in the teaching process in a quality manner.

The relationship between teachers and students with disabilities regarding the subject Nature and Society will depend on a number of factors, including social engagement, learning outcomes and necessary support. For many students with disabilities, the classes of the subject Nature and Society are not a positive experience, especially when it comes to classes spent in nature. Students encounter difficulties: relationships with peers, marginalization and lack of interaction with teachers (Blinde \& McCallister, 1998).

Strugs, Mastropier and McDuffie (2007), emphasize that joint teaching is a strategy to reduce the gap between regular and special education, as well as that teaching practice includes actions between special and regular teachers which are dealing with relevant issues in the classroom. A number of authors have questioned the acquisition of motor skills and changing attitudes among inclusive and non-inclusive teaching in the classes of the subject Nature and Society for students with disabilities, and they came to the conclusion that improvements in attitudes towards inclusion were found in classrooms supported by teachers.

Work with these students enables teachers to share their knowledge and expertise within the class, with students of different abilities, with the application of greater joint flexibility and responsibility. Within a regular process of upbringing and education, an expert teacher, using new teaching strategies and modification of curricula, tends to 
improve the teaching process, in order to achieve an equal, comprehensive participation of students during teaching. Teachers in regular classes tend to plan globally, and need to see the difference in teaching methods in order to meet the needs of individuals.

Teachers are dealing with effective strategies, and they do not always have the necessary knowledge to successfully involve children with disabilities in regular classes. LaMasfer, Gall, Kinchin and Siedentop (1998) identified the lack of support in adaptation, as well as the lack of general knowledge of disability, as well as factors that contribute to the inability of teachers to involve students with disabilities. Students with disabilities are in some way inferior to their peers who do not have developmental problems.

\section{Didactic-methodical specifics of the work of teachers in the teaching of the subject Nature and Society in an inclusive class}

The specificity of providing support in didactic-methodical structuring of the teaching process and learning of students with disabilities depends on the number of students and their specificity. Even teachers with years of experience in working with these students often have the fear, surprise and need for improvisation in direct contact and all from the conclusion that practical work is not sufficient, but also requires theoretical support, selfconfidence, and intuition regarding their students. The ability of teachers to help students with disabilities by adjusting methods, materials and teaching tools, with the help of visual aids, characterized by striking and large letters, documentary or film material, graphic representations, models or practical didactic aids, is necessary. For teaching the subject Nature and Society, the most appropriate methods are multi visual methods, which contribute to the engagement of students in a comprehensive way, with the use of accompanying materials in the form of paintings, posters, plastic materials, toys, etc. In addition to these, there are other possibilities of teaching, for example recording of the teaching process or the use of specific tools.

In this type of class, students respond to shorter sequences of work with sufficient time to repeat and understand the subject that is being processed. Also, it is useful to connect students through the application of work in pairs or groups, as a form of assistance or control of work. Here, the teacher provides students with disabilities with additional time to perform tasks, simplify working procedures, and handle less complex logical tasks. Teachers regularly monitor and motivate students in their work with an emphasis on a clear system of expectations and rules, which are often stressed for students. When assessing knowledge and giving grades, teachers evaluate, depending on the students from the regular classes involved in teaching, which method of assessment to take. In the organization of the teaching process, students need help and support, so they could make progress. In addition, the schedule of activities that will be known to them should be determined. Teachers establish certain communication rights which are clear and well known, speak in a calm and soft way, with more frequent praise of the students.

The didactic methodical process consists of a process of planning and programming based on the initial assessment of the knowledge, skills and abilities of students regarding the subject Nature and Society. The teacher, together with a pedagogue and psychologist, prepares a plan for the subject Nature and Society, and performs an assessment. With individualized programming, teachers predict the implementation of a smaller number of facts and generalizations, abstract content and principles of graduality. The teachers didactically adjust the contents of learning in a clear, understandable and simple way, and 
connect them with the needs of the everyday life of students and the possibilities of their application. They separate only essential things with simplicity, while the practical tasks are chosen so that they are related and in line with textual part of the assignments. Complex tasks are explained and mastered with students by stages, respecting principles ranging from the simpler to the more complex. Students are introduced to simple practical assignments, with clear explanations, while individual student work is based on close examples.

For the purposes of self-learning, teachers indicate what is important in the text, the text contains familiar words, the sentences are short, a cognitive map plan is created, obvious support is provided using the method of demonstration, drawing and practical work in clarifying abstract and complex concepts. During the oral presentation, teachers adapt the words to the student's vocabulary, using clear and shorter sentences focused on what is important, with a certain amount of repetition and checking for the student to understand them. During oral presentations, they use conversations, by asking questions, and adjust the amount of complex content to the intellectual and reading ability of the team of students, with support if necessary. Teachers use sources from reality whenever it possible, and the teaching tools (visual, audible, textual) in a way that the student's attention is guided by observation and directed to key content (Ainscow, Booth, \& Dyson, 2006). Adjustment of the means for easier teaching is based on the development of individualized visual means, free from the details that impede students in understanding the objective reality.

Teachers form the methodological organization of the text with sentences, copying the text in parts, selectively dictating with a sufficient number of repetitions, at a reasonable pace and clarity. The principles of inclusive work should not be contradictory to the general principles of educational work, on the basis of the emotional atmosphere and the sense of security that should be provided to students. Teachers base their educational work on individualization, the student's skills of identification, use of specific and specially adapted didactic material in learning and exercising, while respecting the principles of gradualness.

The progress of students in teaching is planned in well-defined procedures, at a pace that students can follow. Assisting students with disabilities implies that a teacher applies learning methods that will ensure the use of acquired knowledge in new situations.

Teachers adjust didactic supplies and materials, images, applications and other educational instruments to the abilities of students to stimulate their socialization and learning. The forms of work that teachers apply are the same as in the course of regular work, with group work and interactive teaching, work in pairs, a workshop approach and individually tailored tasks. All of the students participate in group work, regardless of their abilities, social background or social status. Teachers encourage students to learn one from another, in order to respect the individual needs of the students based on democratic participation. In groups, students have the opportunity to choose, develop critical thinking and accomplishments, and to work with different sources, with which they are trained for responsibility and mutual help.

It should be noted that inclusion does not require a specific methodology, but harmonization of existing methods and forms of work. Research has shown that teachers who have developed pedagogical tact, understanding and a sense of working with children can do it successfully (Ainscow, Booth, \& Dyson, 2006). Teachers know the lawfulness of the development and the needs of students, so that with regular observation, monitoring and evaluation of students' progress, they have the ability to individualize the educational goals of students. Successful inclusive teachers respect and accept individual differences among students, but they strive to acquire knowledge and skills to work with students with 
disabilities through professional development and practical experience of direct work. These teachers base their work on expert assessments of the students, their possibilities, interests and needs, and adjust the forms, methods and content of their work.

\section{CONCLUSION}

The school, as one of the foundations of a single socio-educational system, is exposed and follows the trends of social changes. Inclusive education represents one of the fundamental human rights today. Inclusion in education means including the students with disabilities in regular schools in order to ensure the quality education and development of each student under the same conditions. Comprehensive student preparedness for inclusive education is a necessary requirement for the successful implementation of inclusive policy and practice. In addition to a number of roles of modern education, a teacher has a special place and role in it as a leader, a mediator in the learning process.

Today, teachers are not sufficiently prepared to work with students with disabilities, because regular education does not provide enough opportunities for the development of knowledge and skills necessary for work in an inclusive environment. First of all, it is necessary to work on future teachers' development of positive attitudes toward inclusion, as well as their encouragement for the planning and realization of the teaching process that meets the needs of all students. In addition to teachers as one of the most important factors of inclusive education, it is necessary to determine what is needed for the content of education that relates to inclusive practice, to include experts of different backgrounds, to compile the opinions of workers who are involved in working with children with disabilities. Also, the preparation of future teachers to work in an inclusive classroom is not enough if everything is reduced to the study of theoretical learning in inclusion, and not on the acquisition of appropriate skills for work in inclusive departments.

The teaching of the subject Nature and Society in an unique way contributes to the learning, personal development and health of students and promotes broad competence and knowledge of activities, growth and development, understanding of the importance of a healthy lifestyle, self-esteem in the context of physical activity (hours spent in nature, hiking, mountain climbing), interpersonal skills, as well as lifelong interest and engagement in activities.

\section{REFERENCES}

Abdullah, N.A., \& Abosi, O. (2014). Attitudes and concerns of regular teachers towards inclusive education in Brunei Darussalam. Asian Journal of Education and e-Learning, 2 (1), 15-23.

Ainscow, M., Booth T., \& Dyson A. (2006). Improving schools, developing inclusion. Routledge, Taylor.

Akhmedova, L. (2019). Features of didactic-methodical competence of primary school teachers. European Journal of Research and Reflection in Educational Sciences, 7(11), 54-58.

Alfaro, V., Kupczynski, L., \& Mundy, M.A. (2015). The relationship between teacher knowledge and skills and teacher attitude towards students with disabilities among elementary, middle and high school teachers in rural texas schools. Journal of Instructional Pedagogies, 16, 1-8.

Amusan, M.A. (2016). Cultivating effective pedagogical skills in in-service teachers: The role of some teacher variables. Journal of the International Society for Teacher Education, 20(1), 83-89.

Arsić, R., Đorđević, S., \& Kovačević, J. (2010). Metodika rada sa decom sa posebnim potrebama - praktikum (Methods of working with children with special needs - Practicum). Leposavić: Teacher Training School in Prizren-Leposavić. In Serbian 
Blinde, E.M., \& McCallister, S.G. (1998). Listening to the voices of students with physical disabilities. Journal of Physical Education, Recreation, and Dance, 69, 64-68.

Darling-Hammond, L., \& Youngs, P. (2002). Defining "highly qualified teachers": What does "scientificallybased research" actually tell us? Educational Researcher, 31 (9).

De Zan, I. (2005). Metodika nastave prirode i društva (Methodology of teaching of Nature and Society. Zagreb: Školska knjiga. In Croatian

European Agency for Development in Special Needs Education (2010): Special Needs Education in the Education System Finland. Retrieved September 10, 2012 from the World Wide Web http://www.europeanagency.org/.

Fahrutdinova, R.A., Yarmakeev, I.E., \& Fahrutdinov, R.R. (2016). Social adaptation of children with disabilities. Turkish Online Journal of Design Art and Communication, 6(Spec.Ed.), 1044-1050.

Forlin, C. (2013). Changing paradigms and future directions for implementing inclusive education in developing countries. Asian Journal of Inclusive Education, 1(2), 19-31.

Gilligan, R. (1998). The importance of schools and teachers in child welfare. Child \& Family Social Work, 3 (1), 13-25

Hoban, S., \& Hoban, G. (2004). Self-esteem, self-efficacy and self-directed learning: Attempting to undo the confusion. International Journal of Self-Directed Learning, 1(2), 7-25.

Ilić, M. (2009). Inkluzivna nastava (Inclusive teaching). East Sarajevo: Faculty of Philosophy University of East Sarajevo. In Serbian

Jorgić, B., Aleksandrović, M., Dimitrijević, L., Radovanović, D., Živković, D., Özsari, M., et al. (2014). The effects of a program of swimming and aquatic exercise on flexibility in children with cerebral palsy. Facta Universitatis Series Physical Education and Sport, 12(2), 71-82.

LaMasfer, K., Gall, K., Kinchin, G., \& Siedentop, D. (1998). Practice of inclusion effective basic specialists. Adapted Physical Activity Quarterly, 15(1), 64-81.

Momčilović, Z., \& Momčilović, V. (2016). Attitudes of the students of the Teacher-Training Faculty in Vranje towards physical education. Facta Universitatis Series Physical Education and Sport, 14 (3), 455-462.

Pianta, R.C. (1999). Enhancing relationships between children and teachers. Washington, DC: American Psychological Association.

Scruggs, T.E., Mastropieri, M.A., \& McDuffie, K.A. (2007). Co-teaching and inclusive classrooms: A metasynthesis of qualitative research. Exceptional Children, 73(4), 392-416.

Shaffer, L., \& Thomas-Brown, K. (2015). Enhancing teacher competency through co-teaching and embedded professional development. Journal of Education and Training Studies, 3(3), 117-125

Sharma, U., \& Desai, I. (2002). Measuring concerns about integrated education in India. Asia and Pacific Journal on Disability, 5(1), 2-14.

Sharma, U., Forlin, C., Loreman, T., \& Earle, C. (2006). Pre-service teachers' attitudes, concerns and sentiments about inclusive education: An international comparison of novice pre-service teachers. International Journal of Special Education, 21(2), 80-93.

Vilotijević, M. (1999). Didaktika: Organizacija nastave (Didactics: Organization of teaching). Zavod za udžbenike i nastavna sredstva. In Serbian

\section{UČITELJ I SPECIFIČNOSTI NJEGOVOG RADA NA IZVOĐENJU INKLUZIVNE NASTAVE IZ PREDMETA PRIRODE I DRUŠTVA U REDOVNIM ODELJENJIMA}

Cilj rada je da se ukaže na specifičnosti rada učitelja u nastavi prirode i društva, primenom različitih oblika nastave, učenja $i$ ocenjivanja, što obezbeđuje jednako pravo $i$ dostupnost obrazovanju i vaspitanju za svu decu, a u skladu sa razvojnim, ličnim obrazovnim i starosnim afinitetima. Rad se bavi potrebom učitelja za obrazovanjem, stručnošću, posedovanjem znanja $i$ sposobnostima za izvođenje inkluzivne nastave kroz predmet prirode $i$ društva u redovnim odeljenjima sa učenicima sa posebnim potrebama. Istaknut je značaj uloge učitelja u nastavnom procesu sa učenicima sa posebnim potrebama, u odnosu na njihovu integraciju $i$ inkluziju $i$ normalan život. Uspešnost jednog obrazovnog sistema ogleda u privlačenju $i$ u odabiru pravih kandidata, sposobnih ljudi za rad u nastavi, koji će doprineti većim i boljim postignućima učenika.

Ključne reči: inkluzija, integracija, učitelj, učenik 